\title{
Mergers and Acquisitions from an Accounting Approach: A Review of the Empirical Literature
}

\author{
Dr. Kyriazopoulos Georgios \\ Assistant Professor of Accounting and Finance Department \\ University of Western Macedonia, 50100 Koila, Kozani, Greece \\ kyrzog@gmail.com \\ kyriazopoulosg@yahoo.com \\ kyriazog@unowm.gr \\ Logotheti Maria-Rafailia \\ Graduate Student of Accounting and Finance Department \\ University of Western Macedonia, 50100, Koila, Kozani, Greece \\ marialogotheti19@gmail.com
}

\begin{abstract}
The European Committee support that the Financial Statements drawn up in accordance with IFRS as issued by the International Accounting Standards Board (IASB) provide users of these statements with a sufficient level of information to enable them to make an informed assessment of the assets and liabilities, financial position, profit and losses and prospects of an issuer. The International Financial Accounting Standards (IFRS) are a sound basis on which to unify accounting standards across the world. In its deliberations on and in elaborating positions to be taken on documents and papers issued by the IASB in the process of developing international accounting standards (IFRS and SIC), the Commission should take into account the importance of avoiding competitive disadvantages for European companies operating in the global marketplace, and, to the maximum possible extent, the views expressed by the delegations in the Accounting Regulatory Committee.This paper attempts to present the accounting methods applied with literature and examples when a merger or an acquisition takes place. This work is mainly directed at students and scientist of accountant and finance. Professionals also will get benefit from this paper because they will learn how to apply and understand the IFRS 3, so as to be able to fill in and analyze financial statements with IFRS. At the beginning we talk about IFRS 3 which is relevant to the accounting methods in mergers and acquisitions that occurred in every European country between big firms. We also show what happened when a big firm wants to takeover a small firm. Afterwards we analyze the steps that are needed to take when a firm wants to takeover a bank or an enterprise. Then we describe the Goodwill that is given from the bidder to the target firm if there is any. But which is the fair value of a takeover. If the bidder wants to allocate the cost should use the notes that we describe to determine it.
\end{abstract}

Keywords: Finance, Accounting, Mergers and Acquisitions

Jel Classification: M41, G34

DOI: $10.7176 / \mathrm{RJFA} / 10-16-01$

Publication date: August $31^{\text {st }} 2019$

\subsection{Introduction}

A business combination is the pooling of separate entities or businesses into a reporting entity. The result of almost all business combinations is that an entity, the acquirer, acquires control of one or more other enterprises of the acquiree. If an entity acquires control of one or more other entities that are not enterprises, the merging of these entities is not a business combination. When an entity acquires a group of assets or net assets that do not constitute an enterprise, it will allocate the cost of the group between the separate identifiable assets and liabilities of the group based on their fair values at the acquisition date. (https://eur-lex.europa.eu/legalcontent/EL/TXT/?uri=CELEX:32004R2236)

A business combination can still be structured in many ways, for legal, tax or other reasons. It may concern the purchase by the entity of the equity of another entity, the purchase of all the net assets of another entity, the takeover of obligations of another entity or the purchase of some of the net assets of another entity that together form one or more undertakings. It may be carried out by the issuance of equity instruments, the transfer of cash, cash equivalents or other assets or a combination thereof. The transaction may be between the shareholders of the merged entities or between one entity and the shareholders of another entity. It may include the establishment of a new entity that will control the merged entities or the net assets transferred or the restructuring of one or more merged entities.

A business combination may also involve the creation of a parent-subsidiary relationship in which the acquirer is the parent and the acquiree is a subsidiary of the acquirer.

Finally, a business combination may involve the purchase of the net assets, including any goodwill, of another 
entity rather than the purchase of the shares of the other entity. This merger does not result in a parent-subsidiary relationship.

The introduction of IFRS in more than 140 countries around the world has created a major challenge for accountants, internal and external auditors, tax authorities and users of corporate financial statements. This challenge is to understand precisely the key differences in the accounting treatment of the totality of financial statements in relation to national accounting standards. In this context, we are called upon to accurately and effectively capture the assets and financial position of enterprises in the "game" of mergers and acquisitions visà-vis all potential users.

Accounting and reporting for business combinations has become the centre of our attention because, although theoretically it should not affect decisions about a purchase or a sale of a company, understanding of reporting can facilitate an agreement on the price of the transaction including the decision as to what information will be provided to business owners. The strategy and the timing of M\&A will be most affected by the accounting method used for the creation of statements on the financial situation and performance of the company before the business combination, at the time of the combination and finally in the periods after the combination (J. Sedlaček, Z. Křžova, E. Hyblova, 2011, Comparison of Accounting Methods for Business Combinations Acta Universitatis Agriculturae et Silviculturae Mendelianae Brunensis Volume LX Number 2, 2012).

Under the new IFRS 3, business combinations include mergers and acquisitions of asset groups that are separate business activities. Almost all mergers and acquisitions controlled by IFRS 3, but some acquisitions are excluded (such as transactions involving joint ventures, consortia, etc.). For certain combinations, the accounting treatment implies the implementation of the cost allocation process. In particular, the acquirer recognizes identifiable assets and liabilities acquired at their fair value at the acquisition date (ie acquisition of control) and the remaining acquisition cost as goodwill, which is not amortized but subject to impairment testing. According to IFRS 3, all corporate transactions should be treated as acquisitions. This means that in any case a buyer (and a seller of course) must be defined, which in the case of a simple takeover of a company seems simple, but we probably do not realize that it is not that simple in the case of more complex transactions such as mergers and acquisitions. From now on, the main cost allocation process begins, including measuring the fair value of the identifiable assets and liabilities that have been redeemed.

Another important change sector and direct impact of the new standards on acquisitions and mergers is certainly the accounting treatment of goodwill for both participants before and after the merger or acquisition. Goodwill is no longer amortized and is subject to impairment testing annually and when there is evidence of impairment. This makes it more difficult to predict future published results and, of course, the impact becomes more immediate for acquisitions not paid after the annual audit. Also, because the impairment test is carried out at the level of cash-generating units, in these cases the risk of impairment is higher, since the impacts of any of these sub-units are not offset. This is why very much attention is paid to the initial definition of these units.

Goodwill cannot be amortized but it is possible to depreciate other identifiable intangible assets of the acquirer with a finite useful life. This implies that the recognition criteria and the possibility of separate valuation are met and that any benefits accruing from the asset benefit the company.

Other important issues where a direct impact is created on the new standard is that any potential repurchase obligations should be recognized at their fair value and that the new rules require that all restructuring costs be excluded unless the acquirer had already had a restructuring plan before transaction. These costs should be treated as post-acquisition costs and burden the first after-sales results. Thus, the assessment and measurement of the potential target should be more detailed, with an emphasis on the analysis of the financial statements of the intangible asset recognition objective and an estimate of possible impairment in the future.

\subsection{Literature review}

As noted by Barth and Schipper (2008), there are four main factors to be considered when designing a "regulatory event study" in which the market reaction to announcements concerning proposed mandated changes in accounting method is investigated: (i) the choice of sample; (ii) the need to control for expectations; (iii) the need to control for related events; and (iv) the need to control for event-time clustering. Nakamura (2005) however explains that using a broad definition of Mergers and Acquisitions could lead to confusion and misunderstanding as it entails everything from pure mergers to strategic alliance. The purpose of a merger is to enjoy synergies. There are four types of synergies that may be identified (Ashamu, S.O.; Akinlabi, B. H.; Durowoju, S.T' and Hassan, A.R., 2011, "The relevance of Accounting Information System in Merger and Acquisition Decision in Nigeria", Interdisciplinary Journal of Contemporary Research in Business Vol.3 No.7): i. Sales synergy, ii. Operating synergy, iii. Management synergy, iv. Investment synergy.

IFRS are a set of principles, methods and guidelines for dealing with specific accounting issues whose application leads to the calculation of the economic result and the preparation of the financial statements of an enterprise in a strictly defined and uniform manner. They are principles and rules that are accepted by the International Accounting Standards Board (IASB) and are embedded within the Framework and Standards. IASB 
(former IASC) is a supranational institution based in Great Britain whose purpose is to issue a high level and generally accepted Accounting Standards (Kontos G., Accounting of Banks Leasing and Factoring 2010). Below at the icon 1 we present the structure of the IASB.

Figure 1 Structure of IASB

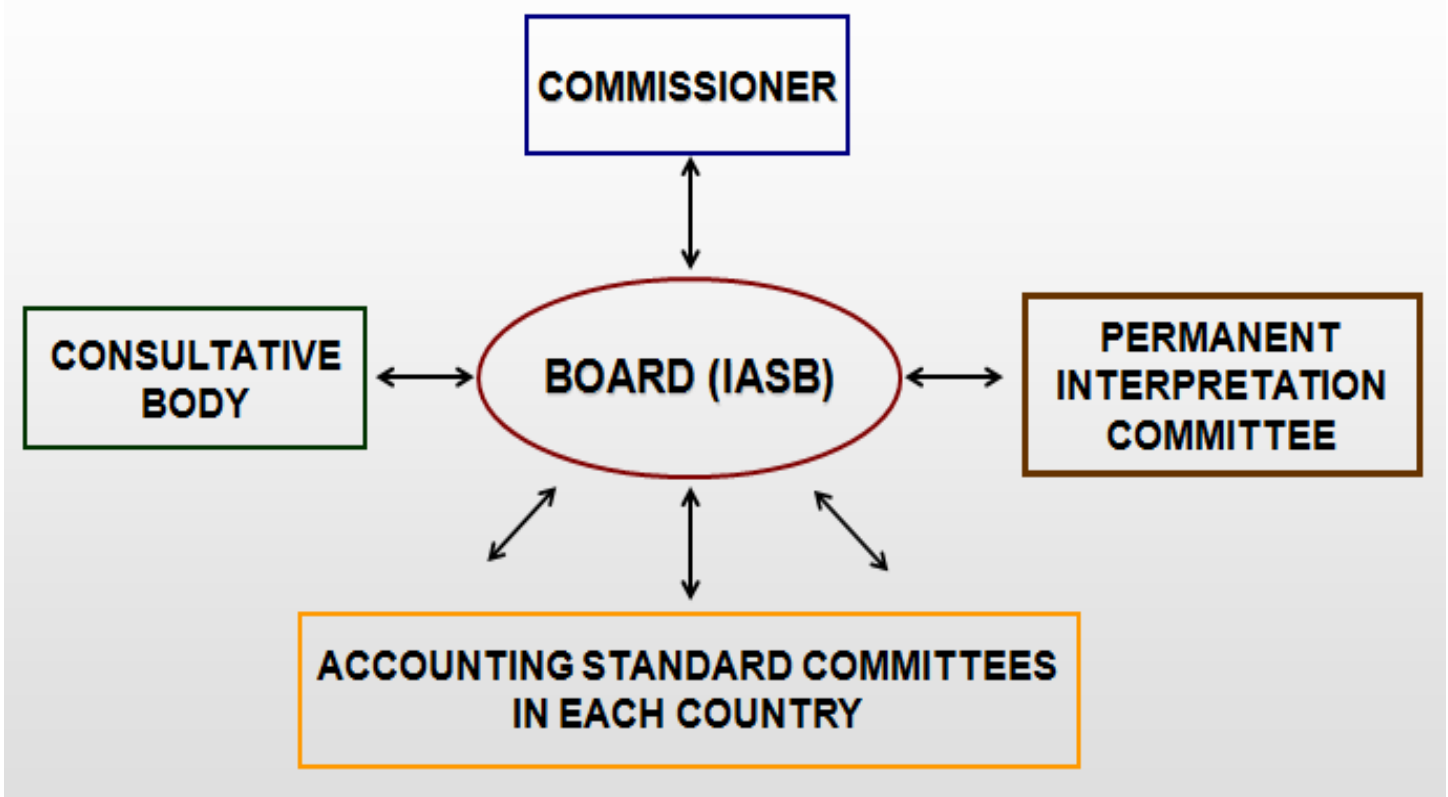

Source: Kontos G., Accounting of Banks Leasing \& Factoring 2010

In the next few lines we will try to describe the procedure for institutionalizing standards in each country. The IASB does not have an enforcement mechanism. Each country alone is competent to decide. Especially for EU countries responsible by the European Parliament following a recommendation from the European Commission Special Institutions: a) at the political level, the ARC (Accounting Regulatory Committee), b) at the technical level, EFRAG (European Financial Reporting Advisory Group).

The IFRS 3 replaces from 01/01/2005 the IAS 22 which has been in force since 1998 for the presentation of consolidated financial statements. So if any merger or acquisition occurred since 2005 they had to use IFRS 3 . It is also necessary to recognize which undertaking gains effective control over the other. In this case, one is the acquirer and the other is the acquiree. Under IFRS 3 one of the following conditions should apply to the acquirer: i) the acquirer obtains the majority of the voting rights of another acquiree, ii) the acquiring undertaking ensures, in agreement with others, the control of the majority of the voting shares of the acquiree, iii) the acquiree can direct the financial and business policy of the acquiree by contract or by law, even if it holds less than $50 \%$ of the votes.

For the "Relevant" legal and economic entity the purpose of IFRS 3 Business Combinations is to determine the financial presentation of the financial data of a business when a business combination is made. The standard determines that all combinations should be depicted using the purchase method (Protopsaltis, 2009). The buyer must recognize the acquirer's assets, liabilities and contingent liabilities at fair value at the acquisition date. Also, the buyer must recognize and present the goodwill of the acquisition, which then and is regularly reviewed for impairment rather than amortized. This standard also defines the elements to be disclosed in the explanatory notes to the financial statements of the joint ventures. Below in Table 1 we describe the history of IFRS 3 
Table 1: The History of IFRS 3

\begin{tabular}{|c|c|c|}
\hline Date & Development & Comments \\
\hline July 2001 & $\begin{array}{l}\text { Project added to IASB agenda (carried over } \\
\text { from the old IASC) }\end{array}$ & History of the project \\
\hline $5 / 12 / 2002$ & $\begin{array}{l}\text { Exposure Draft ED } 3 \text { Business Combinations } \\
\text { and related exposure drafts proposing } \\
\text { amendments to IAS } 36 \text { and IAS } 38 \text { published }\end{array}$ & Comment deadline 4 April 2003 \\
\hline $31 / 4 / 2004$ & $\begin{array}{l}\text { IFRS } 3 \text { Business Combinations (2004) and } \\
\text { related amended versions of IAS } 36 \text { and IAS } \\
\underline{38} \text { issued (IFRS } 3 \text { supersedes IAS 22) }\end{array}$ & $\begin{array}{l}\text { Effective for business combinations for which } \\
\text { the agreement date is on or after } 31 \text { March } \\
2004\end{array}$ \\
\hline $29 / 4 / 2004$ & $\begin{array}{l}\text { Exposure Draft Combinations by Contract } \\
\text { Alone or Involving Mutual Entities published } \\
\text { (These proposals were not finalised, but } \\
\text { instead considered as part of the June } 2005 \\
\text { exposure draft). }\end{array}$ & Comment deadline 31 July 2004 \\
\hline $30 / 6 / 2005$ & $\begin{array}{l}\text { Exposure Draft Proposed Amendments to } \\
\text { IFRS } 3 \text { published }\end{array}$ & Comment deadline 28 October 2005 \\
\hline $10 / 1 / 2008$ & IFRS 3 Business Combinations (2008) issued & $\begin{array}{l}\text { Applies to business combinations for which } \\
\text { the acquisition date is on or after the } \\
\text { beginning of the first annual reporting period } \\
\text { beginning on or after } 1 \text { July } 2009\end{array}$ \\
\hline $6 / 5 / 2010$ & $\begin{array}{l}\text { Amended by Annual Improvements to IFRSS } \\
2010 \text { (measurement of non-controlling } \\
\text { interests, replaced share-based payment } \\
\text { awards, transitional arrangements for } \\
\text { contingent consideration) }\end{array}$ & $\begin{array}{l}\text { Effective for annual periods beginning on or } \\
\text { after } 1 \text { July } 2010\end{array}$ \\
\hline $12 / 12 / 2013$ & $\begin{array}{l}\text { Amended by Annual Improvements to IFRSS } \\
2010-2012 \text { Cycle (contingent consideration) }\end{array}$ & $\begin{array}{l}\text { Applicable for business combinations for } \\
\text { which the acquisition date is on or after } 1 \text { July } \\
2014\end{array}$ \\
\hline $12 / 12 / 2013$ & $\begin{array}{l}\text { Amended by Annual Improvements to IFRSS } \\
\text { 2011-2013 Cycle (scope exception for joint } \\
\text { ventures) }\end{array}$ & $\begin{array}{l}\text { Effective for annual periods beginning on or } \\
\text { after } 1 \text { July } 2014\end{array}$ \\
\hline $12 / 12 / 2017$ & $\begin{array}{l}\text { Amended by Annual Improvements to IFRS } \\
\text { Standards 2015-2017 }\end{array}$ & $\begin{array}{l}\text { Effective for annual periods beginning on or } \\
\text { after } 1 \text { January } 2019\end{array}$ \\
\hline $22 / 10 / 2018$ & $\begin{array}{l}\text { Amended by Definition of a Business } \\
\text { (Amendments to IFRS 3) }\end{array}$ & $\begin{array}{l}\text { Effective for business combinations for which } \\
\text { the acquisition date is on or after the } \\
\text { beginning of the first annual reporting period } \\
\text { beginning on or after } 1 \text { January } 2020 \text { and to } \\
\text { asset acquisitions that occur on or after the } \\
\text { beginning of that period }\end{array}$ \\
\hline
\end{tabular}

Source: www.deloitte.com

IFRS 3 (2008) seeks to enhance the relevance, reliability and comparability of information provided about business combinations (e.g. acquisitions and mergers) and their affects. It sets out the principles on recognition and measurement of acquired assets and liabilities, the determination of goodwill and the necessary disclosures (iasplus.com/en/standards/ifrs/ifrs3).

According to the IFRS organization the IFRS 3 establishes principles and requirements for how an acquirer in a business combination:

- $\quad$ recognizes and measures in its financial statements the assets and liabilities acquired, and any interest in the acquire held by other parties,

- recognizes and measures the goodwill acquired in the business combination or a gain from a bargain purchase,

- determines what information to disclose to enable users of the financial statements to evaluate the nature and financial effects of the business combination,

- measures and recognizes goodwill as of the acquisition date as revised by the International Accounting Standards Board in 2008, the acquirer must,

- measure any tangible assets and liabilities that were acquired

- measure any intangible assets and liabilities that were acquired

- measure the amount of any noncontrolling interest in the acquired business

- measure the amount of consideration paid to the seller. 
Measure tangible assets and liabilities. Measure tangible assets and liabilities at their fair market values as of the acquisition date, which is the date when the acquirer gains control over the acquiree. There are a few exceptions, such as lease and insurance contracts, which are measured as of their inception dates. However, most assets and liabilities should be measured as of the acquisition date. This fair value analysis is frequently done by a third-party valuation firm (accountingtools.com/articles/2017/5/4/acquisition-accounting)

Measure intangible assets and liabilities. Measure intangible assets and liabilities at their fair market values as of the acquisition date, which is the date when the acquirer gains control over the acquiree. This tends to be a more difficult task for the acquirer than the measurement of tangible assets and liabilities, since the acquiree may not have recorded many of these items on its balance sheet. Once measured and recorded as part of the acquisition transaction, intangible assets must be amortized over their useful economic lives. If the lifespan of an intangible asset is considered to be indefinite, do not amortize it until such time as a useful economic life can be determined (accountingtools.com/articles/2017/5/4/acquisition-accounting).

Measure noncontrolling interest. Measure and record the noncontrolling interest in the acquiree at its fair value on the acquisition date. The fair value can be derived from the market price of the stock of the acquiree, if an active market for it exists. This amount is likely to be less per share than the price the acquirer paid to buy the business, since there is no control premium associated with the noncontrolling interest (accountingtools.com/articles/2017/5/4/acquisition-accounting)

Measure consideration paid. There are many types of consideration that may be paid to the seller, including cash, debt, stock, a contingent earnout, and other types of assets. No matter what type of consideration is paid, it is measured at its fair value as of the acquisition date. The following calculation is used to ascertain the total amount of consideration paid: + Fair value of assets paid to seller + Fair value of acquirer equity awards that replace existing acquiree awards - Fair value of liabilities incurred by the seller $=$ Total consideration paid (accountingtools.com/articles/2017/5/4/acquisition-accounting).

The acquirer should include in this consideration calculation the amount of any future payment obligations, such as earnouts. If events occur after the acquisition date, such as the completion of a target under an earnout arrangement, its accounting recognition varies depending on the type of consideration paid. If the contingent payment is in equity, there is no remeasurement of the consideration paid, and any change in the amount of equity issued is noted within the equity section of the balance sheet. If the contingent payment involves an asset or liability, it is remeasured at each subsequent reporting date until the contingent event has been settled, with changes being reported in net income.

Measure goodwill or bargain purchase gain. After all of the preceding steps have been completed, the acquirer must back into the amount of any goodwill or gain on a bargain purchase by using the following calculation:

Consideration paid + Noncontrolling interest - Identifiable assets acquired + Identifiable liabilities acquired (accountingtools.com/articles/2017/5/4/acquisition-accounting).

A somewhat different approach is used when nonprofit entities are involved. When a nonprofit acquirer gains control of an acquiree whose fair value is greater than the consideration paid for it, the acquirer is said to have received an inherent contribution (accountingtools.com/articles/2017/5/4/acquisition-accounting).

If this calculation results in a bargain purchase (formerly known as negative goodwill), then the acquirer has paid less for the acquire than the fair values of its assets and liabilities indicate that it is worth. A bargain purchase is recognized as a gain as of the acquisition date (wallstreetprep.com).

The many steps noted here to record an acquisition cannot always be completed in time to be accurately recorded in the accounting period when an acquisition is completed. If it appears that the accounting will be delayed, the acquirer should report its best estimates in the relevant accounting period, and then adjust those figures later, based on facts and circumstances that existed as of the acquisition date. Information arising at a later date may result in subsequent changes to asset and liability values, but they should not be used to retroactively adjust the recordation of the original acquisition entry (accountingtools.com/articles/2017/5/4/acquisition-accounting).

Now if we would like to compare IFRS3 that it applies in European mergers and acquisitions and GAAP ASC805 we will find many similarities but also some differences that are (gaapdynamics.com):

1. If operating leases are acquired in a business combination and the acquiree is also the lessee, the accounting under ASC 805 and IFRS 3 is essentially the same. However, if the acquiree is the lessor, the accounting under the two standards differ (gaapdynamics.com).

2. Under ASC 805, both contingent assets and liabilities are recognized at the acquisition at fair value, if fair value can be determined before the end of the measurement period (i.e. whether or not the contingency is probable, possible, or remote under ASC 450). Under IFRS 3, contingent liabilities are recognized at the acquisition date fair value if there is a present obligation arising from past events (i.e. obligation is "probable" under IAS 37). However, unlike U.S. GAAP, contingent assets are never recognized under IFRS (gaapdynamics.com).

3. If an entity acquires a controlling portion of a business but there is a non-controlling interest present, how the 
non-controlling interest is measured may differ under ASC 805 and IFRS 3. U.S. GAAP requires a noncontrolling interest to be measured at fair value at the acquisition date. Unlike U.S. GAAP, IFRS gives the acquirer the option to either: 1) measure the non-controlling interest at fair value at the date of acquisition; or 2) measure the non-controlling interest at its proportion of the fair value of the identifiable net assets of the acquired entity. Let's take a look at an example to see how the accounting of the non-controlling interest may differ (gaapdynamics.com).

4. U.S. GAAP provides an irrevocable "option" for the acquiree to reflect the new basis of accounting (as a result of purchase accounting) in its separate financial statements This is referred to as "pushdown" accounting as the acquirer's new basis of accounting for their acquisition is "pushed down" to the separate financial statements of the acquiree. ASC Subtopic 805-50 provides guidance on when this option can be elected and exactly "how" pushdown accounting should be performed. Unlike U.S. GAAP, IFRS is silent and has no guidance when it comes to pushdown accounting and therefore this approach is generally not performed at the acquiree separate financial statement level (gaapdynamics.com).

The measurement period is the period during which adjustments can be made to amounts originally recorded as the result of an acquisition at the acquisition date. Amounts may change as the result of new information that is obtained about facts and circumstances that existed at the acquisition date, or due to the acquisition accounting not being completed as of the fiscal year end of the acquirer. Prior to ASU 2015-16, both ASC 805 and IFRS 3 required measurement period adjustment to be made retrospectively by "recasting" prior periods. However, as the result of ASU 2015-16, under U.S. GAAP, measurement period adjustments are no longer required to be made retrospectively but instead, adjustments are made prospectively by adjusting amounts in the period in which the adjustment is determined. IFRS still requires adjustments to be made retrospectively (gaapdynamics.com).

Mergers and acquisitions (M\&A) occur when businesses combine to achieve corporate objectives. In an acquisition, a company purchases another company's assets, identifiable business segments, or subsidiaries. In a merger, a company purchases another company in its entirety. In either situation, there is a union of businesses. Along with mergers and acquisitions come special accounting principles. This guide will cover purchase accounting for mergers and acquisitions. Accounting for an M\&A transaction can be broken down into the following five steps: a) Identify a business combination, b) Identify the acquirer, c) Measure the cost of the transaction, d) Allocate the cost of a business combination to the identifiable net assets acquired and goodwill, e) Account for goodwill (corporatefinanceinstitute.com).

Identify a business combination means that the main purpose of a business combination is to achieve some form of synergy. In the combination, the acquirer hopes to assume control of the acquiree. Numerous legal, taxation, or other business-related strategies may be used to structure an M\&A deal. When analyzing an M\&A, a common approach is the acquisition method, wherein the deal is viewed from the perspective of the combining entity that is identified as the acquirer. The acquirer assumes control of the acquiree's assets, liabilities, and any other business pieces pertinent to the acquiree's operations (corporatefinanceinstitute.com).

Identify the Acquirer means that in every business combination, there is always an acquirer, the party that retains control of the combined entity. Control is defined as the "power to govern the financial and operating policies of an entity or business so as to obtain benefits from its activities." In most combinations, an entity is said to have obtained control when it acquires more than one-half of the other entity's voting rights, unless such a majority stake does not constitute control. Although it may be difficult to identify an acquirer in an M\&A, indicators of the acquirer may include (corporatefinanceinstitute.com): i) The entity with the greater fair value, if there is a significant difference, is likely to be the acquirer; or ii) The entity giving up cash or other assets in the deal is likely to be the acquirer; or iii) The entity whose management is the definitive dominator in the deal is likely to be the acquirer (corporatefinanceinstitute.com).

These are only some of the possible factors in assessing control. Numerous factors are involved in determining which entity has the power to govern the post-merger firm. There also exist reverse acquisitions. In a reverse acquisition, the acquirer is the entity whose equity interests have been acquired and the issuing entity is the acquiree. For example, a private entity arranges to have itself "acquired" by a smaller public entity as a means of obtaining a stock exchange listing. In actuality, the private entity is the acquirer if it has the power to govern the financial and operating policies of the legal parent. Note that the acquirer need not be the larger of the two entities (corporatefinanceinstitute.com).

Measure the cost of the transaction means that the cost of a business combination is the sum of: i) The fair values, at the acquisition date, of assets, liabilities (incurred or assumed), and equity instruments issued by the acquirer; plus ii) Any costs directly attributable to the business combination.

The acquisition date is the date on which the acquirer effectively obtains control of the acquiree. Assets obtained and liabilities incurred or assumed by the acquirer must be measured at their fair values at the date of acquisition. If any of the cost of a combination is deferred, the fair value of that deferred component is calculated by discounting the amounts payable to their present value at the date of acquisition, including any premium or discount likely to be incurred in the settlement (corporatefinanceinstitute.com). 


\subsection{Accounting Methods in Mergers and Acquisitions.}

Hampton (1989) claimed that "a merger is a combination of two or more businesses in which only one of the corporations survives" (Hampton, 1989, p. 394). Using simple algebra, Singh's (1971) concept of merger can be symbolized by A $+\mathrm{B}=\mathrm{C}$, whereas Hampton's (1989) can be represented by A $+\mathrm{B}=\mathrm{A}$ or B or C.

Mergers and acquisitions are transactions in which the ownership of firms, banks other business organizations, or their operating units are transferred or consolidated with other entities. As an aspect of strategic management, M\&A can allow enterprises to grow or downsize, and change the nature of their business or competitive position.

From a legal point of view, a merger is a legal consolidation of two entities into one, whereas an acquisition occurs when one entity takes ownership of another entity's stock, equity interests or assets. From a commercial and economic point of view, both types of transactions generally result in the consolidation of assets and liabilities under one entity, and the distinction between a "merger" and an "acquisition" is less clear. A transaction legally structured as an acquisition may have the effect of placing one party's business under the indirect ownership of the other party's shareholders, while a transaction legally structured as a merger may give each party's shareholders partial ownership and control of the combined enterprise. A deal may be euphemistically called a merger of equals if both CEOs agree that joining together is in the best interest of both of their companies, while when the deal is unfriendly (that is, when the management of the target company opposes the deal) it may be regarded as an "acquisition".

Corporate Mergers and Acquisitions are something very crucial for any country's economy. This is so because the Corporate Mergers and Acquisitions can result in significant restructuring of the industries and can contribute to rapid growth of industries by generating Economies of Scale. Although the concept of Merger and Acquisition are different from one another, both can be used as engines of growth. Corporate Mergers and Acquisitions are instruments which can instantly result in expansion of production capacity. Corporate Mergers and Acquisitions results in Skill Transfer and other Sharing Activities. After a company is merged with another or is acquired by a bigger one, the former gains in terms of comparative advantage. After a Corporate Merger or Acquisition, production takes place on a large scale. This large scale production generates economies of scale. So, in a way Corporate Mergers and Acquisitions help companies to attain rapid growth. In case of a Corporate Merger or Acquisition, the distribution of value between the shareholders of the target company and the bidder company depends significantly on the relative bargaining power of the bidder firm and the target firm.

A merger or acquisition not only benefits the big firm but also benefits the target firm. The target firm can get such a high bid that it exceeds the real market value of the target company. This can be possible in two cases. Firstly, when acquiring of the target firm is really crucial for the firm who wants to acquire it and when the target firm is more valuable to the acquiring firm than to any other bidder firm. Secondly, when the bidder firm is confident of acquiring comparative advantage in a short span through the acquisition of the target firm. Before a merger and acquisition take place the bidder have to make the above steps that they seen in the icon 2 so as the merger or the acquisition will be as much as successful.

Figure 2: The steps for a completed and successful Merger and Acquisition

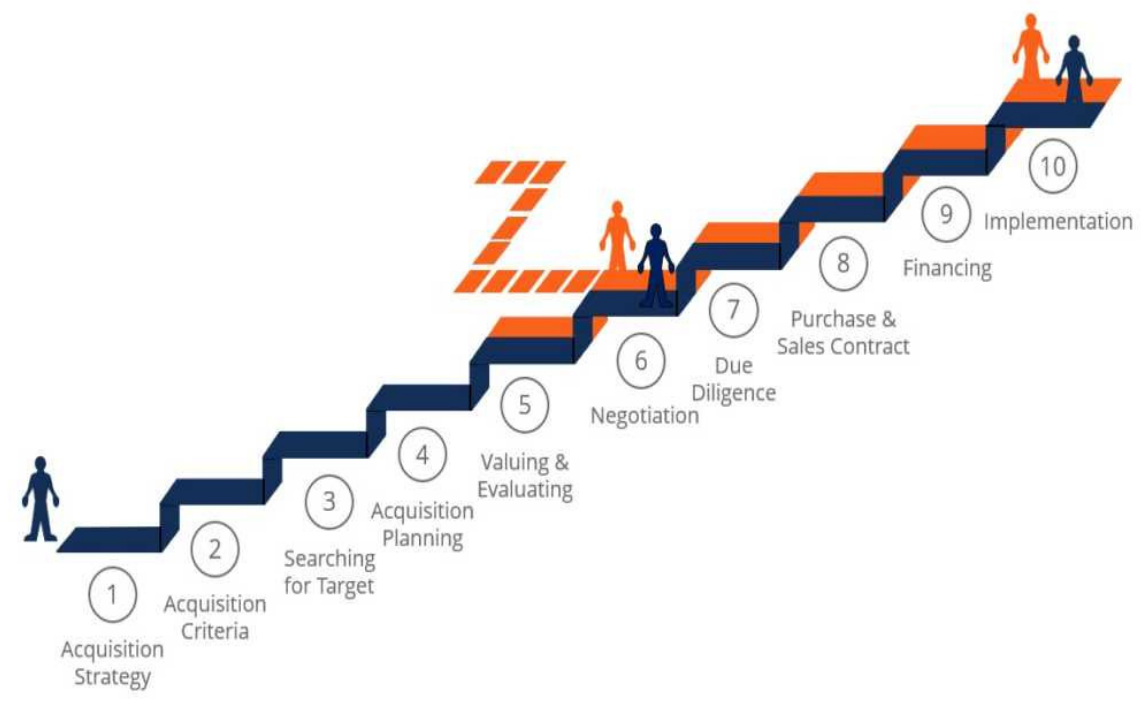

Source: https://corporatefinanceinstitute.com/cources/advanced-financial-modeling-mergers-acquisitions/

Determining the cost of acquisition is a serious matter. The cost of acquisition is determined by the sum of: i) The cash or cash equivalents paid or the fair value (at acquisition date) of any other assets transferred by the acquiree for the acquisition of control of the acquiree. These rewards must be measured at fair value at the 
acquisition date, ii) The extra costs directly related to the particular consolidation and such may be the fees of auditors, accountants and legal advisors who take part in the redemption procedures.

The IFRS 3 also provides that if the consideration received is paid to the acquiree on a date subsequent to the acquisition date, then the amounts to be paid at a later date should be discounted at the appropriate discount rate in the purchase date.

Account should also be taken of the following:

- If the financial instruments (eg shares) used as consideration for an acquisition are traded on a regulated market then their fair value is the trading price,

- In determining the acquisition cost, future losses or other expenses that will arise in the future will not be recognized as they will be recognized as expenses for the years that they use.

- Expenses related to the liabilities assumed should not be included in the cost of the acquisition, but should increase the value of the liabilities.

- The cost of issuing the financial instruments is not included in the cost of the acquisition but should reduce the "proceeds" from the issue.

In merger accounting the financial statements of the parties to the combination are aggregated and presented as though the combining entities had always been part of the same reporting entity.

Two accounting methods are implemented on mergers and acquisitions: A) the pooling of interests and B) the purchase arrangements. Copeland and Weston (1988) defined them as follows, In a pooling arrangement the income statements and balance sheets of the merging firms are simply added together. On the other hand, when one company purchases another, the assets of the acquired company are added to the acquiring company's balance sheet along with an item called goodwill which is the difference between the purchase price and the book value of the acquired company's assets [and, by regulation, should] be written off as a charge against earnings after taxes in a period not to exceed 40 years. (Copeland and Weston, 1988, p. 365).

The criteria for the equity method in this case (where there is no control relationship) are: one entity has significant influence over the operating and financial policies of the other, or alternatively, the accounting entity holds a joint venture interest in the other. (Ted J. Fiflis 1981).

According to the IFRS 3 there are three main accounting methods of mergers and acquisitions. These are: A) Pooling of Interest Method (Amalgamation in nature of merger), B) Purchase Method (Amalgamation in nature of purchase), and C) The cost Method.

The 1st Pooling of Interest Method considers mostly that a) Balance sheet of both companies, would be combined at book value without revaluing assets or creation of goodwill and liabilities, b) Balances of $\mathrm{P} / \mathrm{L}$ a/c of both companies would be added or else would be transferred to General Reserve A/C, c) Any difference between consideration paid to the transferor company and amount recorded as nominal value of share capital of to the transferor company is adjusted in general reserves.

The 2nd Purchase Method considers mostly that: a) Here the assets \& liabilities are valued at their book value or on basis of fair value, b) Total Assets-Liabilities=Net Asset Value (NAV), c) If Consideration Paid $=\mathrm{NAV}=$ Effect same as Pooling of Interest Method, d) If Consideration Paid $>\mathrm{NAV}=$ Assets recorded at increased price in consolidated B/S, Excess Amount=Goodwill, e) Goodwill written off over a period of five years. f) If Consideration Paid $<\mathrm{NAV}=\mathrm{Assets}$ recorded at written down value in consolidated $\mathrm{B} / \mathrm{S}$, Less amount $=$ Adjusted as Capital Reserve.

How do accountants determine whether to pool or purchase? A set of rules specifies the characteristics of combinations that can receive pooling or, alternatively, purchase treatment. The rules are intended to distinguish between two types of combinations: one represents firms joining forces, and the other represents one firm buying the assets and liabilities of another. Theoretically, in the first instance, the combined firm receives pooling treatment, and in the second, it receives purchase. Regardless of the intent of the rules, in reality firms can often choose their accounting treatment by structuring the combination carefully, though at possible extra cost (John R. Walter "Pooling or Purchase: A Merger Mystery" Federal Reserve Bank of Richmond Economic Quarterly Volume 85/1 Winter 1999).

In the table 2 below we write down the differences between the two methods. 
Table 2 Differences Between the two Basic Methods

\begin{tabular}{|c|c|c|}
\hline $\begin{array}{l}\text { BASIS FOR } \\
\text { COMPARISON }\end{array}$ & $\underline{\text { POOLING OF INTEREST METHOD }}$ & $\underline{\text { PURCHASE METHOD }}$ \\
\hline Meaning & $\begin{array}{l}\text { Pooling of Interest Method of } \\
\text { accounting is one in which the assets, } \\
\text { liabilities and reserves are combined and } \\
\text { shown at their historical values, as of the } \\
\text { date of amalgamation. }\end{array}$ & $\begin{array}{l}\text { Purchase Method, is an accounting method, } \\
\text { wherein the assets and liabilities of the } \\
\text { transferor company are shown at their market } \\
\text { value in the books of the transferee company, } \\
\text { as of the date of amalgamation. }\end{array}$ \\
\hline Applicability & Merger & Acquisition \\
\hline $\begin{array}{l}\text { Assets and } \\
\text { Liabilities }\end{array}$ & Appear at book values. & Appear at fair market values. \\
\hline Recording & $\begin{array}{l}\text { All the assets and liabilities of the } \\
\text { companies undergoing merger are } \\
\text { aggregated. }\end{array}$ & $\begin{array}{l}\text { Only those assets and liabilities are recorded in } \\
\text { the books of transferee company, which are } \\
\text { taken over by it. }\end{array}$ \\
\hline Reserves & $\begin{array}{l}\text { The identity of transferor company's } \\
\text { reserves is kept intact. }\end{array}$ & $\begin{array}{l}\text { The identity of the transferor company's } \\
\text { reserves except statutory reserves is not kept } \\
\text { intact. }\end{array}$ \\
\hline $\begin{array}{l}\text { Purchase } \\
\text { Consideration }\end{array}$ & $\begin{array}{l}\text { Difference in the amount of puchase } \\
\text { consideration and share capital is } \\
\text { adjusted with reserves. }\end{array}$ & $\begin{array}{l}\text { Surplus of deficit of purchase considertaion } \\
\text { over the net asset acuiqred, should be credited } \\
\text { or debited, as capital reserves or goodwill. }\end{array}$ \\
\hline
\end{tabular}

Source: Surbhi S (2017) https://keydifferences.com/difference-between-pooling-of-interest-and-purchasemethod.html

Business combinations use "pooling of interest method" if the requisite degree of continuity of the rights and risks of their original investments exists for shareholders of both the acquiring company and the acquired company. All other acquisitions are treated as "purchases method."

Below are four explanations for the above tables 3 and 4

1. Fixed Assets of firm $Z$ are overvalued $50 €$ (table 4)

2. Current assets of firm $Z$ are also overvalued at $€ 100$ (table 4)

3. Consideration Paid is $€ 150$ worth equity shares (table 4)

4. Goodwill $=€ 150$ (Balancing figure table 4).

Table 3: Pooling of Interest Method

\begin{tabular}{|c|c|c|c|}
\hline Participants in a merge & Firm A & Firm B & Post Merger Firm Z=A+B \\
\hline Current Assets & 500 & 300 & $500+300=800$ \\
\hline Fixed Assets & 200 & 100 & $200+100=300$ \\
\hline Total Assets & $\mathbf{7 0 0}$ & $\mathbf{4 0 0}$ & $\mathbf{7 0 0}+\mathbf{4 0 0}=\mathbf{1 1 0 0}$ \\
\hline Current Liabilities & 400 & 200 & $400+200=600$ \\
\hline Long Term Liabilities (debentures as an example) & 150 & 150 & $150+150=300$ \\
\hline Equity (Share Capital) & 150 & 50 & $150+50=200$ \\
\hline Total Liabilities & $\mathbf{7 0 0}$ & $\mathbf{3 0 0}$ & $\mathbf{7 0 0}+\mathbf{4 0 0}=\mathbf{1 1 0 0}$ \\
\hline
\end{tabular}

Source: Authors according the IFRS3

Table 4: Purchase Method

\begin{tabular}{|c|c|c|c|}
\hline Participants in a merge & Firm A & Firm B & Post Merger Firm Z=A+B \\
\hline Current Assets & 500 & 300 & $500+300=900$ \\
\hline Fixed Assets & 200 & 100 & $200+100=350$ \\
\hline Goodwill & & & $\mathbf{1 5 0}$ \\
\hline Total Assets & $\mathbf{7 0 0}$ & $\mathbf{4 0 0}$ & $\mathbf{7 0 0}+\mathbf{4 0 0}+\mathbf{1 5 0}=\mathbf{1 2 5 0}$ \\
\hline Current Liabilities & 400 & 200 & $400+200=600$ \\
\hline Long Term Liabilities (debentures as an example) & 150 & 150 & $150+150=300$ \\
\hline Equity (Share Capital) & 150 & 50 & $150+50+150=350$ \\
\hline Total Liabilities & $\mathbf{7 0 0}$ & $\mathbf{3 0 0}$ & $\mathbf{7 0 0}+\mathbf{4 0 0}=\mathbf{1 2 5 0}$ \\
\hline
\end{tabular}

Source: Authors according the IFRS3

Pooling of interests is a method of accounting that mainly applied for amalgamations the object of which is to account for the amalgamation as if the separate businesses of the amalgamating companies were intended to be continued by the transferee company. Accordingly, only minimal changes are made in aggregating the individual financial statements of the amalgamating companies. Generally speaking, amalgamations fall into two broad categories. In the first category are those amalgamations where there is a genuine pooling not merely of the assets and liabilities of the amalgamating companies but also of the shareholders' interests and of the businesses of these 
companies. Such amalgamations are amalgamations which are in the nature of 'merger' and the accounting treatment of such amalgamations should ensure that the resultant figures of assets, liabilities, capital and reserves more or less represent the sum of the relevant figures of the amalgamating companies. In the second category are those amalgamations which are in effect a mode by which one company acquires another company and, as a consequence, the shareholders of the company which is acquired normally do not continue to have a proportionate share in the equity of the combined company, or the business of the company which is acquired is not intended to be continued (cleartax.in/s/as-14-accounting-for-amalgamations).

The core principles in IFRS 3 are that an acquirer measures the cost of the acquisition at the fair value of the consideration paid; allocates that cost to the acquired identifiable assets and liabilities on the basis of their fair values; allocates the rest of the cost to goodwill; and recognizes any excess of acquired assets and liabilities over the consideration paid (a 'bargain purchase') in profit or loss immediately. The acquirer discloses information that enables users to evaluate the nature and financial effects of the acquisition. In October 2018 the International Accounting Standards Board issued Definition of a Business (Amendments to IFRS 3). The amendments narrowed and clarified the definition of a business. They also permit a simplified assessment of whether an acquired set of activities and assets is a group of assets rather than a business.

Another case take place when an acquirer gains control of an acquiree whose fair value is greater than the consideration paid for it, the acquirer is said to have completed a bargain purchase. A bargain purchase transaction most commonly arises when a business must be sold due to a liquidity crisis, where the short-term nature of the sale tends to result in a less-than-optimum sale price from the perspective of the owners of the acquiree (accountingtools.com/articles/bargain-purchase-definition-and-usage.html).

For the acquirer to account for a bargain purchase, follow these steps:

1. Record all assets and liabilities at their fair values.

2. Reassess whether all assets and liabilities have been recorded.

3. Determine and record the fair value of any contingent consideration to be paid to the owners of the acquiree.

4. Record any remaining difference between these fair values and the consideration paid as a gain in earnings. Record this gain as of the acquisition date (accountingtools.com/articles/bargain-purchase-definition-andusage.html)

Now we are going to examine the carryover method of accounting. When there is a merger of nonprofit entities, a new nonprofit entity is created. A merger occurs when the existing entities cede control to a new nonprofit. The carryover method is used to account for this event. Under the carryover method, the assets and liabilities of the merged entities are combined as of the merger date; this is the date on which the merger transaction becomes effective. There are several adjustments required to the combination of the assets and liabilities of the merging entities in order to create properly merged financial statements.

The adjustments are (accountingtools.com/articles/what-is-the-carryover-method-of-accounting.html):

- Contract modifications. If a merger transaction will alter the terms of a contract, adjust the classification of the impacted asset or liability to match the state of the altered contract.

- Reclassifications. If the entities are using different methods to account for their assets and liabilities, adjust the impacted items to reflect a consistent method of accounting. This does not mean that the merged entity can revise accounting options that were restricted to the initial acquisition or recognition of an item. For example, if the fair value option was originally taken for an asset, this option cannot be revoked by the merged entity.

- Intra-entity transactions. If there were any transactions between the merging entities prior to the merger transaction, remove these intra-entity transactions from the merged assets, liabilities, and net assets.

When accounting for a merger, it is not permissible to recognize any new assets or liabilities, such as internally-developed intangible assets, which may be allowed under an acquisition transaction. A merged entity is considered a new entity, so it does not report any activities prior to the merger date. The beginning financial statements of the entity incorporate the adjustments just noted for the effects of contract modifications, reclassifications, and intra-entity transactions. In general, the new entity resulting from a merger transaction under the carryover method shall disclose information in its financial statements that allow readers to evaluate the nature and financial effect of the transaction. To do so, the following disclosures are needed (accountingtools.com/articles/what-is-the-carryover-method-of-accounting.html):

- The name and description of the entities that were merged

- The date of the merger

- The reasons for the merger

- For each merged entity, the amounts on the merger date of each major class of assets, liabilities, and net assets, as well as the nature and amounts of any other significant assets or liabilities not recognized; examples are conditional promises receivable and payable.

- The nature and amount of any significant adjustments made to eliminate intra-entity transactions or to 
standardize accounting policies.

- If the new entity is publicly held, and the merger does not occur at the beginning of its fiscal year, disclose revenue and changes in all types of net assets as though the merger had taken place at the beginning of the year. If the entity is also providing comparative information for prior years, this additional information is to be provided for the prior years. If it is impracticable to provide this additional information, explain why.

There is another case that needed to be figured. Pushdown accounting is the process of using the acquiring entity's basis of accounting to prepare the financial statements of the acquired entity. This means that the assets and liabilities of the acquiree are updated to their fair values as of the acquisition date.

These changes appear in the financial statements of the newly-acquired entity. Pushdown accounting is not required for entities that are not registrants with the Securities and Exchange Commission i.e., public entities (accountingtools.com/articles/2017/5/16/pushdown-accounting).

Let as explain know the purchase accounting adjustment. Purchase accounting is the practice of revising the assets and liabilities of an acquired business to their fair values at the time of the acquisition. This treatment is required under the various accounting frameworks, such as GAAP and IFRS. Common revisions of asset and liability values include (accountingtools.com/articles/what-is-a-purchase-accounting-adjustment.html): i) Recording inventory at its fair value, ii) Recording fixed assets at their fair values, iii) Recording intangible assets at their fair values.

In particular, intangible assets (such as customer lists and non-compete agreements) were not recorded on the books of the acquiree at all, so their recordation as assets is entirely new. These changes have an impact on the accounting books of the acquirer, which are known as purchase accounting adjustments. The adjustments are caused by the altered values of the assets and liabilities. For example (accountingtools.com/articles/2017/5/16/pushdown-accounting): i) An increase in the valuation of inventory means that the acquirer will record an increased amount of cost of goods sold when the inventory is eventually sold, ii) An increase in the valuation of fixed assets requires an increased amount of depreciation over time, iii) The presence of new intangible assets requires the recognition of amortization over time.

Given the nature of these examples, it can be seen that purchase accounting adjustments frequently increase the recognized amount of expenses for a company in future periods, though these expenses are of the non-cash variety. In particular, the amount of amortization expense can be substantial (if not overwhelming), so that this particular purchase accounting adjustment can cause the acquirer to record substantial losses until such time as the intangible assets have been fully amortized. A business frequently explains the impact of purchase accounting adjustments in the notes accompanying its financial statements, so that readers can understand how acquisitions have skewed the results reported by the business (accountingtools.com/articles/2017/5/16/pushdown-accounting).

An acquirer should recognize separately an intangible asset of the acquiree at the acquisition date only if it satisfies the definition of an intangible asset:

- Separately identifiable

- A resource that is controlled by the entity

- A probable source of future economic benefits

- Its fair value can be measured reliably

An asset meets the identifiability criterion in the definition of an intangible asset if it:

- Is separable (traceable); or

- $\quad$ Arises from contractual or other legal rights

For identifiability, separability, as well as contractual and legal rights, are taken into account. Accounting principles aim to reflect that an entity's equity value is reflected in the value of its intangible assets. Under previous accounting rules, the identifiability of separate net assets relied purely on the ability of the entity to identify an asset or liability separately. Current accounting rules examine the amount an acquirer is willing to pay for an acquisition and allocate it through a more thorough set of intangible asset recognition criteria. Note that not all items that are deemed to add value to the entity in question should be recognized separately. This is usually because the entity does not control the resource in question. For example, the skills of a workforce embodied in a group of people does not meet the intangible asset definition, as the entity often has insufficient control over the actions of the group (corporatefinanceinstitute.com).

Under IFRS, the expenditure during the research part of an in-process research and development (IPRD) project must be expensed. However, subsequent expenditures during the development phase of a project (the commercial development of existing research knowledge) may be capitalized post-acquisition. Under US GAAP, neither past expenditure on research nor on development is treated as a separable asset acquired as part of the acquisition. The main separately recognized intangible assets are a) Trade names, b) Non-compete agreements, c) Customer lists, d) Licensing and e) Patented technology (corporatefinanceinstitute.com).

Below we describe another two cases. The case of the identifiable asset and the case of the non-controlling interest. 
i) An identifiable asset is a separate asset that has been acquired through a business combination. These assets are assigned a fair value and recorded in the financial records of the acquirer. Once the fair values of all identifiable assets and liabilities have been assigned, the aggregate amount is subtracted from the purchase price paid to the owners of the acquiree; the residual is recorded as goodwill in the balance sheet of the acquirer Subject to the recognition criteria, the acquirer recognizes separately, as part of allocating the cost of the combination, only the identifiable assets, liabilities, and contingent liabilities of the acquiree that existed at the acquisition date. Therefore, the acquirer should a) Recognize liabilities for terminating or reducing the activities of the acquiree as part of allocating the cost of the combination. This is only recognized when the acquiree has, at the acquisition date, an existing liability for restructuring in its accounts, b) Not recognize liabilities for future losses or other costs expected to be incurred as a result of the business combination (corporatefinanceinstitute.com). Examples of identifiable assets are buildings, computer equipment, machinery, office equipment, and vehicles. Intangible assets can also be considered identifiable assets. An asset is considered to be identifiable if it can be separately disposed of (accountingtools.com/articles/2017/5/12/identifiable-asset).

ii) A non-controlling interest is an ownership position in a corporation that is not sufficiently large for an investor to exercise operational control over the entity. The bulk of all investors have a non-controlling interest, since the number of shares they own in proportion to the total is so small. A non-controlling interest does not have to be one that has less than $50 \%$ of the shares outstanding. A lesser proportion of ownership can result in a person acquiring a board seat, which does provide a measure of control. An investor with a non-controlling interest does not consolidate the results of the investee with its own financial statements (accountingtools.com/articles/2017/5/12/non-controlling-interest).

Another very important issue in an acquire is the calculation of the fair value and the Goodwill. Goodwill is the excess of the purchase price paid for an acquired entity and the amount of the price not assigned to acquired assets and liabilities. It arises when an acquirer pays a high price to acquire another business. This asset only arises from an acquisition; it cannot be generated internally. Goodwill is an intangible asset, and so is listed within the long-term assets section of the acquirer's balance sheet. The value of goodwill is highly subjective, especially since it does not independently generate cash flows. Consequently, the accounting standards require that an acquirer regularly test its goodwill asset for impairment, and to write down the asset if impairment can be proven (accountingtools.com/articles/2017/5/9/goodwill).

Goodwill is an intangible asset generated from the acquisition of one entity by another. It is the difference between the price paid by the acquirer for a business and the amount of that price that cannot be assigned to any of the individually-identified assets and liabilities acquired in the transaction. The acquirer must recognize goodwill as an asset as of the acquisition date. The goodwill calculation is as follows (accountingtools.com/articles/how-to-calculate-goodwill.html):

Goodwill $=($ Consideration paid + Fair value of noncontrolling interest $)-($ Assets acquired - Liabilities assumed).

When calculating the total amount of consideration paid as part of the derivation of goodwill, consider the following additional factors (accountingtools.com/articles/how-to-calculate-goodwill.html):

- Fair value of assets paid. When the acquirer transfers its assets to the owners of the acquiree as payment for the acquiree, measure this consideration at its fair value. If there is a difference between the fair value and carrying amount of these assets as of the acquisition date, record a gain or loss in earnings to reflect the difference. However, if these assets are simply being transferred to the acquiree entity (which the acquirer now controls), do not restate these assets to their fair value; this means there is no recognition of a gain or loss.

- $\quad$ Share-based payment awards. The acquirer may agree to swap the share-based payment awards granted to employees of the acquiree for payment awards based on the shares of the acquirer. If the acquirer must replace awards made by the acquiree, include the fair value of these awards in the consideration paid by the acquirer, where the portion attributable to pre-acquisition employee service is classified as consideration paid for the acquiree. If the acquirer is not obligated to replace these awards but does so anyways, record the cost of the replacement awards as compensation expense. Once goodwill has been recorded by the acquirer, there may be subsequent analyses that conclude that the value of this asset has been impaired. If so, the amount of the impairment is recognized as a loss, which reduces the carrying amount of the goodwill asset. Goodwill cannot be generated internally; it can only be recognized through the acquisition of another business (accountingtools.com/articles/how-to-calculate-goodwill.html).

On the date of acquisition, goodwill arising from the business combination should be recognized in the balance sheet of the acquirer as an intangible asset. The asset is measured as the excess of the acquisition cost over the acquirer's interest in the fair value of the assets acquired and the liabilities assumed (corporatefinanceinstitute.com). 
Figure 3: Implications of new standards on the contents of reported goodwill
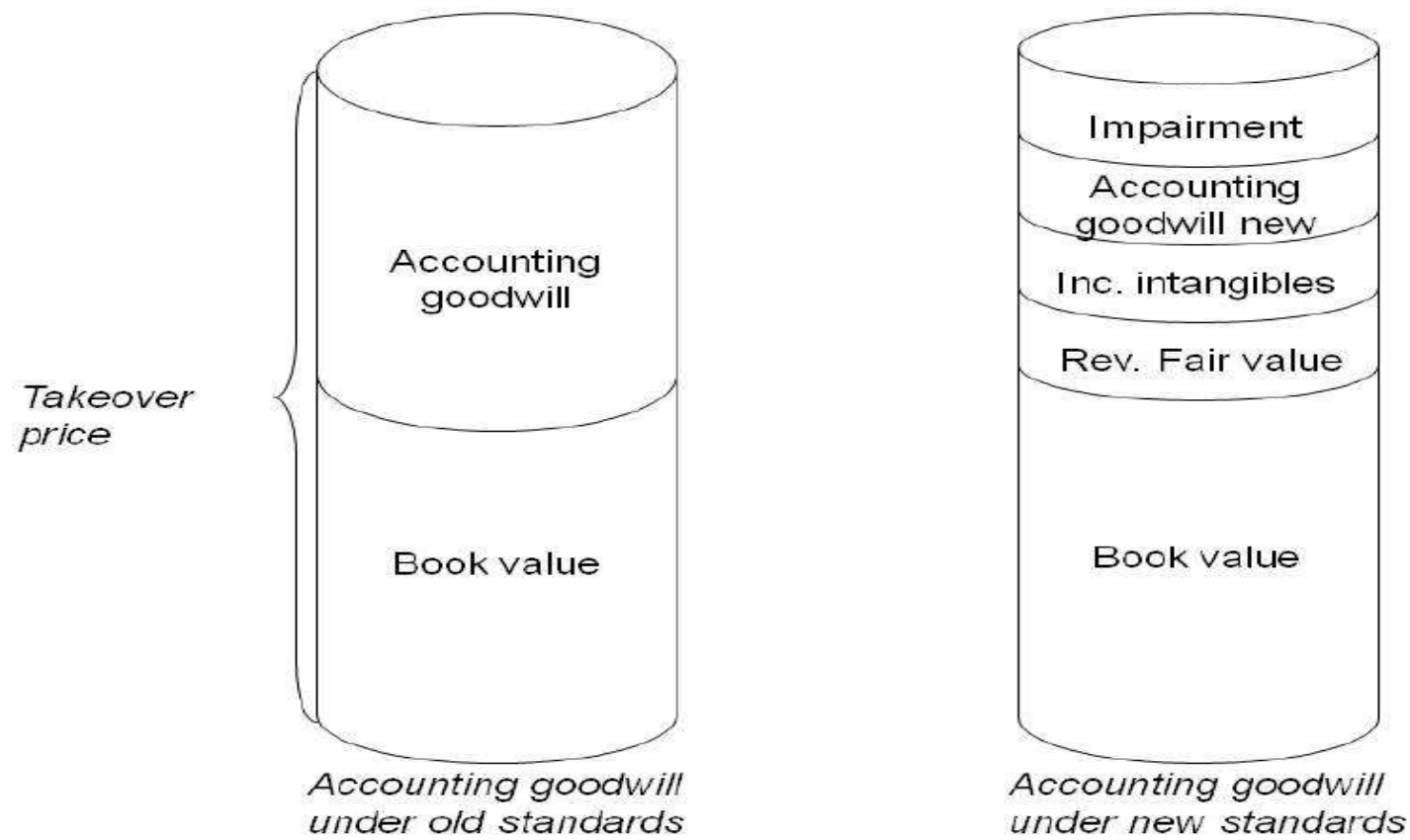

Source: M.P.Lycklama à Nijeholt Y.K.Grift J.M.J. Blommaert "Goodwill measuring value creation of acquisitions: an empirical research In the table 5 below we present an example of goodwill's calculation". Discussion Paper Series nr: 12-21, Utrecht School of Economics, Tjalling C. Koopmans Research Institute, August 2012.

Table 5 Goodwill Example Calculation

\begin{tabular}{|l|l|l|l|}
\hline Fair Value of consideration & & & \\
\hline Cash & 500000 & & Fair Value \\
\hline Ordinary shares of acquirer & 800000 & & Fair Value \\
\hline Debt & 1700000 & & Fair Value \\
\hline Acquisitions Costs & 100000 & & $\begin{array}{l}\text { Included in the acquisition cost if directly } \\
\text { attributable to the cost of acquisition. }\end{array}$ \\
\hline Total & & 3100000 & \\
\hline $\begin{array}{l}\text { Fair Value of net assets } \\
\text { acquired }\end{array}$ & & & $\begin{array}{l}\text { Adjustment to bring book values in line with } \\
\text { fair values }\end{array}$ \\
\hline Book value of target & 1300000 & & $\begin{array}{l}\text { Adjustment to bring book values in line with } \\
\text { fair values }\end{array}$ \\
\hline Fair value adjustments & 180000 & & $\begin{array}{l}\text { Recognition of intangible asset not recognized } \\
\text { on target's balance sheet }\end{array}$ \\
\hline $\begin{array}{l}\text { Fair value adjustments } \\
\text { Intangible assets }\end{array}$ & 120000 & & \begin{tabular}{l} 
\% of target acquired in business combination \\
\hline $\begin{array}{l}\text { Total } \\
75 \% \text { of target acquired }\end{array}$
\end{tabular} \\
\hline $\begin{array}{l}\text { Goodwill arising on the } \\
\text { acquisition of target } \\
(3100000-2200000)\end{array}$ & & 900000 & $\begin{array}{l}\text { Goodwill arising (subsuming net assets not } \\
\text { identifiable/separable as part of the business } \\
\text { combination). }\end{array}$ \\
\hline
\end{tabular}

Source: Authors Calculation according corporatefinanceinstitute.com

Negative goodwill arises when the acquisition cost of a business combination is less than the fair value of the net assets acquired. If the initial calculation of the goodwill is deemed appropriate, the negative goodwill is written off and a gain is recognized in the income statement. Negative excess is recognized immediately in profit or loss for the period. This situation usually only arises as part of a distressed sale of a business (corporatefinanceinstitute.com).

The published price at the date of exchange of an equity instrument provides the best measurement of value and is commonly used, except in rare circumstances. Other valuation methods should be considered only if the acquirer can demonstrate that the published price at the date of exchange is an unreliable indicator of fair value and that other evidence and valuation methods more reliably measure fair value. If the published price at the date of exchange is an unreliable indicator, the fair value of those instruments can, for example, be estimated by 
referencing their proportional interest in the fair value of the acquirer or the proportional interest in the fair value of the acquiree obtained, whichever is the clearer measurement (corporatefinanceinstitute.com).

An acquirer should use the following notes that described to the table 6 so as to be able to determine the fair value of a target firm:

Table 6: Useful notes for an acquirer for determination the fair value of a firm

\begin{tabular}{|c|c|}
\hline Allocation of acquisition cost & Fair value determination \\
\hline $\begin{array}{l}\text { Financial instruments traded in } \\
\text { active market. }\end{array}$ & Current market values. \\
\hline $\begin{array}{l}\text { Financial instruments not traded } \\
\text { in an active market. }\end{array}$ & $\begin{array}{l}\text { Use estimated values of comparable instruments of entities with similar } \\
\text { characteristics. }\end{array}$ \\
\hline $\begin{array}{l}\text { Receivables, beneficial contracts } \\
\text { and other identifiable assets. }\end{array}$ & $\begin{array}{l}\text { Present values of the amounts to be received, determined at appropriate } \\
\text { current interest rates, fewer allowances for uncollectibility and collection } \\
\text { costs. }\end{array}$ \\
\hline $\begin{array}{l}\text { Inventories of finished goods and } \\
\text { merchandise. }\end{array}$ & $\begin{array}{l}\text { Selling prices less the sum of the costs of disposal and a reasonable profit } \\
\text { allowance for the selling effort of the acquirer. }\end{array}$ \\
\hline Inventories of work in progress. & $\begin{array}{l}\text { Selling prices of finished goods less the sum of: i) Costs to complete, ii) } \\
\text { Costs of disposal, iii) A reasonable profit allowance for the completing } \\
\text { and selling effort based on profit for similar finished goods. }\end{array}$ \\
\hline Inventories of raw materials. & Current replacement costs. \\
\hline Land and buildings. & Market values. \\
\hline Plant and equipment. & $\begin{array}{l}\text { Market values (An acquirer may need to estimate fair value using an } \\
\text { income, cash flow or a depreciated replacement cost approach if no } \\
\text { current market values are given). }\end{array}$ \\
\hline Intangible assets. & $\begin{array}{l}\text { Determine fair value: i) By reference to an active market, ii) If no active } \\
\text { market exists, on the basis that reflects the amounts the acquirer would } \\
\text { have paid for the assets based on the best information available. }\end{array}$ \\
\hline $\begin{array}{l}\text { Net employee benefit assets or } \\
\text { liabilities for defined benefit } \\
\text { plans. }\end{array}$ & $\begin{array}{l}\text { The present value of the defined benefit obligation less the fair value of } \\
\text { plan assets. }\end{array}$ \\
\hline $\begin{array}{l}\text { Accounts and notes payable, } \\
\text { long-term debt, liabilities, }\end{array}$ & $\begin{array}{l}\text { The present values of amounts to be disbursed in settling the liabilities } \\
\text { determined at appropriate current interest rates. }\end{array}$ \\
\hline & $\begin{array}{l}\text { However, discounting is not required for short-term liabilities when the } \\
\text { difference between the nominal and discounted amounts is not material. }\end{array}$ \\
\hline $\begin{array}{l}\text { Onerous contracts and other } \\
\text { identifiable liabilities. }\end{array}$ & $\begin{array}{l}\text { The present values of amounts to be disbursed in settling the obligations } \\
\text { determined at appropriate current interest rates. }\end{array}$ \\
\hline Contingent liabilities. & $\begin{array}{l}\text { The amounts that a } 3 \text { rd party would charge to assume those contingent } \\
\text { liabilities. Such an amount should reflect all expectations about possible } \\
\text { cash flows. }\end{array}$ \\
\hline
\end{tabular}

Source: https://corporatefinanceinstitute.com

The Moribund Effect reflects the fact that brand value remains unchanged, giving the impression to those who use annual financial reports that acquired brands, once bought, are in effect placed on a shelf and ignored. They do not grow in absolute terms or in relationship to the performance of the company. If the company grows over time, because the value of these acquired brands remains at their transaction measurement, their relative weight or percentage of the marketing capitalization of the firm actually decreases. This vivid loss of weight underscores the use of the term "'moribund." Logic would suggest that they should, at least, move in step with the 
company growth rate. In some cases even, where successful marketing has lifted brand revenues and profit above the historic trend, they should grow faster than the company. All of these possibilities are ignored because of the way the business combination standards are worded. Value ignored is value lost (Roger Sinclair, Kevin Lane Keller, 2017, Brand value, accounting standards, and mergers and acquisitions: "The Moribund Effect" Journal of Brand Management (2017). doi:10.1057/s41262-016-0025-1).

Except the three main accounting methods for mergers and acquisitions we have another one for business combination. All business combinations will be accounted for using the market method. The market method examines the business combination on the part of the acquiring entity recognized as the acquirer. The acquirer purchases net assets and recognizes the acquired assets, liabilities and contingent liabilities as liabilities, including those that were not previously recognized by the acquiree. The measurement of assets and liabilities is not affected by the transaction nor are any additional assets or liabilities of the acquirer due to the transaction because they are not the subject of the transaction. Applying the market method involves the following steps:

(a) identification of the acquirer,

(b) the measurement of the cost of the business combination

(c) the allocation, at the acquisition date, of the cost of a business combination to the acquiree's assets and liabilities and contingent liabilities. Recognition of the acquirer

The acquirer will be recognized for each business combination. The acquirer is the merged entity that acquires control of the other related entities or entities. Because the market method examines the business combination on the part of the acquirer, it considers that one of the parties to the transaction can be identified as the acquirer.

Control is the power to direct the economic and business policies of an entity or business so you can benefit from its activities. A merged entity will be deemed to have acquired control of another merged entity when it acquires more than half of the voting rights of the other entity unless it can be shown that that ownership is not a control. Even if one of the merged companies does not acquire more than half of the voting rights of another merged entity, it could acquire control of that other entity if, as a result of the merger, it acquires:

(a) more than half the voting rights of the other entity, in agreement with other investors,

(b) power to direct the economic and business policies of the other entity, on the basis of a statute or agreement,

(c) power to appoint or terminate the majority of the members of the board of directors or equivalent governing body of the other entity,

(d) power to cast a majority of the votes in meetings of the board of directors or an equivalent governing body of the other entity.

\section{Conclusions}

The changes that take place in accounting science every year are many. There are also differences in some minor issues between the countries applying IAS and IFRS. Therefore scientists, or occupied people who involved with accounting, and they wish to be kept informed should regularly consult the communications of the IFRS Committee -IASB and the corresponding European and domestic IFRS legislation. Accountants should also be kept abreast of new IT systems related to accounting software and packages and they should apply the latest and the most modern.

\section{References}

Ashamu, S.,O., Akinlabi, B., H.; Durowoju, S.,T., and Hassan, A.,R., (2011), The relevance of Accounting Information System in Merger and Acquisition Decision in Nigeria. Interdisciplinary Journal of Contemporary Research in Business Vol.3 No.7

Barth, M.,E., and Schipper, K., (2008), Financial Reporting Transparency. Journal of Accounting, Auditing \& Finance, 23, 173-190.

Copeland, T.,E., and Weston, J.,F., (1988), Financial Theory and Corporate Policy. 3rd edition, Reading: Addison-Wesley.

Fiflis, T., J., (1981), Accounting for Mergers, Acquisitions and Investments, in a Nutshell: The Interrelationships of, and Criteria for, Purchase or Pooling, the Equity Method, and Parent-Company-Only and Consolidated Statements. The Business Lawyer Vol. 37, No. 1 (Nov. 1981), pp. 89-140 Published by: American Bar Association www.jstor.org/stable/40686345 Page Count: 52

Hampton, J.,J., (1989), Financial Decision Making: Concepts, Problems, and Cases. 4th edn. New Jersey: Prentice-Hall.

Kontos G., (2010), Accounting of Banks Leasing and Factoring. Second Edition, Published by Diplographia, ISBN 978-960-89648-1-5 Athens 2010

Kyriazis D., (2002). "Mergers and Acquisitions" Second Edition improved and enhanced. Published by Diplographia Athens.

Lycklama, M.P., Grift, Y.K., Blommaert, J.M.J., (2012), Goodwill measuring value creation of acquisitions: an empirical research In the table 5 below we present an example of goodwill's calculation". Discussion Paper 
Series nr: 12-21, Utrecht School of Economics, Tjalling C. Koopmans Research Institute, August 2012

Nakamura, H.R., (2005), Motives, Partner Selection and Productivity Effects of M\&As: The Pattern of Japanese Mergers and Acquisition. Journal of Business Economics and Management, 91(3) 334 - 456.

Protopsaltis, N. (2009), Examples of application in IAS and IRFS and Interpretations. Volume A \& B. Athens: Stamouli Publications.

Sedlaček, J., Křižova, Z., Hyblova, E., (2012), Comparison of Accounting Methods for Business Combinations. Acta Universitatis Agriculturae et Silviculturae Mendelianae Brunensis Volume LX Number 2, 2012

Sinclair, R., Keller, K., L., (2017), Brand value, accounting standards, and mergers and acquisitions: The Moribund Effect. Journal of Brand Management (2017). Volume 24, Issue 2, March 2017 doi:10.1057/s41262-0160025-1

Walter J., R., (1999), Pooling or Purchase: A Merger Mystery. Federal Reserve Bank of Richmond Economic Quarterly Volume 85/1 Winter 1999

\section{Internet (15/7/2019)}

accountingtools.com/articles/2017/5/4/acquisition-accounting accountingtools.com/articles/bargain-purchase-definition-and-usage.html accountingtools.com/articles/2017/5/16/pushdown-accounting accountingtools.com/articles/what-is-a-purchase-accounting-adjustment.html accountingtools.com/articles/2017/5/12/identifiable-asset accountingtools.com/articles/2017/5/12/non-controlling-interest accountingtools.com/articles/2017/5/9/goodwill accountingtools.com/articles/how-to-calculate-goodwill.html cleartax.in/s/as-14-accounting-for-amalgamations corporatefinanceinstitute.com Deloitte. deloitte.com/gr/en.html European Financial Reporting Advisory Group. efrag.org eur-lex.europa.eu/LexUriServ/LexUriServ.do?uri=OJ:L:2008:340:0017:0019:EL:PDF gaapdynamics.com International Accounting Standards Board, “International Accounting Standards”, IASB, 2002. www.ifrs.org/ ifrs.org/issued-standards/list-of-standards/ifrs-3-business-combinations/ iasplus.com/en/standards/ifrs/ifrs3 https://eur-lex.europa.eu/legal-content/EL/TXT/?uri=CELEX:32004R2236 keydifferences.com/difference-between-pooling-of-interest-and-purchase-method.html by Surbhi S (2017) wallstreetprep.com 